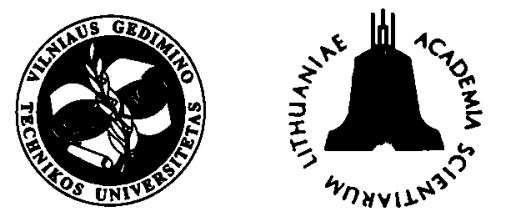

\title{
INDICATORS FOR ENERGY PERFORMANCE EFFICIENCY CERTIFICATION IN THE LITHUANIAN RESIDENTIAL BUILDINGS
}

\author{
Egidijus Juodis ${ }^{1}$, Bronia Jablonska, Martine A. Uyterlinde, Henk F. Kaan, Mark T. van Wees ${ }^{2}$ \\ ${ }^{1}$ Vilnius Gediminas Technical University, Saulètekio al. 11, LT-2040 Vilnius, Lithuania \\ Egidijus.Juodis@ap.vtu.lt \\ ${ }^{2}$ ECN Energy Research Centre of the Netherlands, The Netherlands
}

Received 25 July 2002; accepted 16 Jan 2003

\begin{abstract}
Energy performance certification (EPC) of buildings results in a label for the buildings. Every label has to correspond to a fixed energy consumption per year. Energy consumption taken as a basis for the certification is to reflect efficiency of energy use in buildings and stimulate the occupiers to become more aware of the effect of their behaviour. The method of energy performance efficiency calculation is proposed and numerical values of annual energy consumption are elaborated on the ground of these two aims, European Union requirements and Dutch experience as energy performance efficiency indicators.
\end{abstract}

Keywords: energy performance certification, energy efficiency indicator, annual energy consumption, heating, ventilation, residential buildings, heat gains.

\section{Introduction}

The goal of energy performance certification (EPC) is to assess the total energy efficiency of a building and to provide information on energy efficiency improvements. There are two reasons why energy performance efficiency certification is to be implemented in Lithuania. The first one is to comply with the European Union requirements, the second expresses an urgent necessity to lower energy consumption in buildings thus decreasing expenses for the maintenance of buildings. These general tasks include, amongst others, a subtask - establishing energy performance efficiency indicators.

In the European Union, EPC is regarded as a promising measure to increase energy efficiency in buildings, and is the subject of existing and proposed EU legislation. Countries that intend to enter the EU must comply with the SAVE Directive (93/76/EEC), which provides in Article 2: "Member States shall draw up and implement programmes on the energy certification of buildings. Energy certification of buildings, which shall consist of a description of their energy characteristics, must provide information for prospective users concerning a building's energy efficiency. Whereas appropriate, certification may also include options for the improvement of these energy characteristics." However, it is clear that the Directive allows considerable flexibility, both in terms of the choice of implementation instruments and the scope of the programmes selected [1].
Furthermore, the EU institutions have been developing a proposed directive on energy performance in buildings, which would require Member States to adopt a methodology for calculating the integrated energy performance of buildings, based upon a common harmonised methodology.

In Lithuania, an EPC for buildings can serve as one of the instruments to increase the quality of the building stock. Therefore, the EPC can be linked to programmes on building maintenance.

Definition of energy performance certification is based on the Draft Directive on energy performance in buildings [2]. The energy performance of a building is the total energy efficiency of a building, reflected in one or more numeric indicators which have been calculated, taking into account insulation, installation characteristics, design and positioning, own energy generation and other factors that influence the net energy demand. Furthermore, the energy performance certificate of a building is an officially recognised certificate in which the result of calculation of the energy performance of a building is presented.

This paper presents the methodology and proposals for establishing EPC numeric indicators.

The energy performance certification scheme is the calculation method and translation to a certificate or label. The energy performance certification programme is the scheme embedding. 


\section{Method}

The certification methodology results in a label for buildings, expressing the level of energy efficiency [3]. The label is given for numeric indicators corresponding to a fixed energy consumption per year. In addition, a system of points is added in order to identify the measures that can be taken to increase energy efficiency. The basis for the energy consumption indicators is a calculation of heat losses and gains.

The following issues have been taken into account in establishing indicators.

\section{Calculated versus measured energy consumption}

The energy consumption that is taken as a basis for the certification should not be influenced by behaviour of the occupiers, because it is the quality of the building itself that is the subject to certification, not the energy consumption as such. In order to avoid these influences, the calculated energy consumption should be taken as a basis for the certification. However, whenever data about measured energy consumption are available, those data should be included in the certificate in order to compare "reasonable" consumption (calculated) to real consumption (measured). This may stimulate the occupiers to become more aware of the effect of their behaviour.

\section{Energy conservation measures}

The EPC should also offer possibilities for occupiers to be upgraded into a higher category, if energy conservation measures are carried out. Hence, apart from the calculated or measured energy consumption, energy conservation measures with their (theoretical) energy savings should be identified. Thus, EPC has to include an adequite number of energy consumption levels.

\section{Adequate but simple method}

Furthermore, some practical constraints are taken into account in establishing the indicators. The method has to be inexpensive and easy to design and implement, and at the same time complex enough to give a reliable basis for labelling. This has to be achieved by choosing a straightforward energy consumption calculation, and introducing a point system for the characteristics not included in the calculation. In addition, the Excel implementation of the EPC scheme should allow a trained auditor to perform an audit of a complete multifamily building in at most four hours. Finally, the scheme has to be suitable both for new and existing buildings, and should allow extension in the future, for instance, to buildings in the public sector.

\section{The proposed energy rating system}

Energy performance certification should be based on clear and strictly defined assumptions. There are two main approaches based on different philosophy which are used when establishing energy rating scales.

The first one was developed by imposing the following constraints: a) the index should tend to zero when the normalised annual energy cost is too large, and $b$ ) the index should tend to $100 \%$ where there is no need to purchase energy [4]. Relationship between the index of energy performance and normalised annual energy cost looks like Gauss' probability curve with two extremes. That is when the house is energy efficient, the index of energy performance can be improved only if some economically unjustified expenses are undertaken. Lower extreme reflects situation when expenses are unjustified because of inherent low energy efficiency of the building. An upper extreme means that when the house is energy efficient, the index of energy performance can be improved only if some economically unjustified expenses are undertaken. In Lithuania similar approach is considered in the National Programme of energy efficiency increasing [5-7]

The second approach establishes the energy performance rating in terms of annual energy use or annual energy cost per $\mathrm{m}^{2}$. Energy labelling becomes more or less arbitrary, in accordance with local point of view what thermal performance is anticipated being of good level.

Numeric indicators are expressed in various ways. The most known are consumption values $\mathrm{kWh}$ per sq. $\mathrm{m}$ of total heated area or in natural gas equivalent [8]. In their turn, buildings are divided into cathegories in accordance with their volume, number of floors or ratio volume/external surface $[9,10]$. In the Lithuanian case statistics contains information data only of number of buildings, area and number of floors; we will follow this division.

All buildings are divided into categories in accordance with their total energy use $\mathrm{kWh} / \mathrm{m}^{2}$.a $(5-7$ cathegories). Every step of energy efficiency improvement requires more effort and saved energy percentage is less. The ratio of energy consumption very efficient/ efficient cathegories lies amongst 1,06 and 1,21 in countries where EPC is implemented [4]. In this investigation the ratio is assumed between 1,15 (at most effective level) and 1,06 (at lowest level).

Building envelope thermal insulation requirements described in the Lithuanian Building Regulation STR 2.05.01:1999 [11] correspond to the most particular Scandinavian and Canadian Regulations. Hence energy performance of the buildings built after the Regulation has come in force should be assessed "very good" (label B ). Label A reflects the lowest energy consumption level that could be achieved if reasonable energy saving measures are implemented in the new housing. On the other hand, low label could be assigned to the buildings which envelope's U-values conform to the requirements of former Soviet Regulation (label E ).

Thus labelling of energy performance conforms to natural steps:

label $\mathbf{A}$ - excellent, annual energy use is $15 \%$ less of the level $B$;

label B - very good, corresponds to STR 2.05.01:1999

[11], assuming $70 \%$ exhausted air heat recovery;

label C - good, corresponds to RSN 143-92 [12]; 
label D - satisfactory;

label E - basic, corresponds to the Soviet Regulations.

Energy performance efficiency depends on the ratio of heated area versus the area of building envelope. Hence energy performance labelling table for various types of residential houses should be elaborated.

Lithuanian Building Regulations, concerning thermal properties of the building envelope, deals with eight types of the buildings: one-floor, one-two floors attached, two floors, one-three floors of complicated shape, three-four floors, five floors, six-nine floors, ten and more floors. The results of the annual heat consumption for heating and ventilation are given in Table 4.

The next chapter explains the figures given in Table 4.

\section{Establishing values of energy consumption indica- tors}

\section{Presumptions}

Annual energy use of the building is given by the equation:

$$
Q+Q_{r}=Q_{h}+Q_{v}+Q_{W}+Q_{t}-Q_{g}
$$

where: $Q$ is the building energy use for heating;

$Q_{r}$ - the heat recovered from auxiliary equipment, heating systems and environment;

$Q_{h}$ - the heat used for space heating;

$Q_{v}$ - the heat used for ventilation;

$Q_{n}$ - the heat required for hot water; tem.

$Q_{1}$ - the total of heat losses due to the heating sys-

$Q_{g}-$ the internal and solar heat gains.
Calculation of the annual energy use for heating is based on LST EN832 [13]. Energy certification intends to improve energy efficiency of buildings. Some of equation components can vary very much for the same building type.

Heat required for hot water preparation $Q_{n}$ is not directly related to the thermal properties of building envelope. Heat losses due to the heating system $Q_{1}$ include additional heat loss due to non-uniform temperature distribution, characteristics of the control and piping systems, heat generator losses. Heat generator and distribution system losses are not included in the specific heat loss coefficient of the building, hence they are not considered further. Heat consumption is calculated for all building, figures are not valid for a single appartment.

Heat recovery

Heat recovery is not usual in Lithuanian residential buildings. It is met in new housing only, therefore heat recovery is the subject for energy efficiency improvement, foreseen in very efficient houses. Efficiency of exhausted air heat utilisation is assumed $70 \%$.

\section{Space heating}

Permissible annual heat use for the space heating of new dwelling houses is given in Table 1. Annual heat use is derived from limit value of specific heat losses $H_{T R}$ established by STR 2.05.01:1999 [10]. The height of a room is assumed $2,65 \mathrm{~m}$ (as in the National Programme). The heated area, in general, is equal to the total area, excluding single cases in the country houses. The total heat loss $Q_{l}$ of a single zone at uniform internal temperature is:

$$
Q_{l}=H_{T R}\left(\Theta_{i}-\Theta_{e}\right) 24 t, \mathrm{kWh} / \mathrm{a},
$$

\begin{tabular}{|c|c|c|c|c|c|}
\hline \multirow{3}{*}{ No } & \multirow{3}{*}{ Description } & \multirow{3}{*}{$\begin{array}{c}\text { Total } \\
\text { heated } \\
\text { area, } \mathrm{m}^{2}\end{array}$} & \multirow{3}{*}{$\begin{array}{c}\text { Limit value } \\
\text { of specific } \\
\text { heat losses, } \\
H_{T R}, \mathrm{~W} / \mathrm{K}\end{array}$} & \multirow{2}{*}{\multicolumn{2}{|c|}{$\frac{\text { Derivative values }}{\text { Limit value of annual heat demand }}$}} \\
\hline & & & & & \\
\hline & & & & $\mathrm{kWh} / \mathrm{m}^{2} \cdot \mathrm{a}$ & $\mathrm{kWh} / \mathrm{m}^{3} . \mathrm{a}$ \\
\hline \multirow{2}{*}{1} & \multirow{2}{*}{ One-floor family houses } & 60 & 95 & 163 & 65 \\
\hline & & 120 & 190 & 163 & 65 \\
\hline \multirow{2}{*}{2} & \multirow{2}{*}{$\begin{array}{l}\text { One-two floor (incl. mansard) family } \\
\text { house }\end{array}$} & 100 & 130 & 133 & 52,2 \\
\hline & & 250 & 310 & 128 & 50,2 \\
\hline \multirow{2}{*}{3} & \multirow{2}{*}{$\begin{array}{l}\text { One-three floor (incl. mansard), of } \\
\text { complicated shape family houses }\end{array}$} & 180 & 210 & 120 & 47.0 \\
\hline & & 400 & 470 & 121 & 47,5 \\
\hline \multirow{2}{*}{4} & \multirow{2}{*}{ Two-floor attached houses } & 250 & 270 & 111 & 43,6 \\
\hline & & 550 & 570 & 108 & 42,3 \\
\hline \multirow{2}{*}{5} & \multirow{2}{*}{ 3-4 floor dwelling houses } & 500 & 470 & 96,8 & 38,0 \\
\hline & & 1800 & 1450 & 82.9 & 32,5 \\
\hline \multirow{2}{*}{6} & \multirow{2}{*}{ 5-floor dwelling houses } & 1500 & 1200 & 82,4 & 32,3 \\
\hline & & 4000 & 2750 & 70,3 & 27,6 \\
\hline \multirow{2}{*}{7} & \multirow{2}{*}{ 9-floor tower shape dwelling houses } & 2500 & 1900 & 78,2 & 30,3 \\
\hline & & 5000 & 3200 & 65,9 & 25,8 \\
\hline 8 & 5-12 floor dwelling houses & $\begin{array}{l}\text { More } \\
5000 \\
\end{array}$ & $0,6 \mathrm{~A}_{\mathrm{h}}$ & 61,8 & 24,2 \\
\hline
\end{tabular}

Table 1. Permissible heat demand for the space heating of a dwelling house 
where: $\Theta_{i}$ is the internal set-point temperature, ${ }^{\circ} \mathrm{C}$, $\Theta_{i}=20^{\circ} \mathrm{C}$;

$\Theta_{e}$ is the average external temperature during the calculation period, ${ }^{\circ} \mathrm{C}, \Theta_{e}=0,5^{\circ} \mathrm{C}$;

$t$ is the duration of the calculation period, $t=220$ days;

$H_{T R}$ is the specific transmission heat loss coefficient of the building, $\mathrm{W} / \mathrm{K}$.

The heat loss coefficient of the building

$$
H=H_{T R}+H_{V},
$$

where: $H_{V}$ - the ventilation specific heat loss coefficient, $\mathrm{W} / \mathrm{K}$.

\section{Ventilation loss}

For comfort and hygienic reasons a minimum ventilation rate is needed when the building is occupied. This minimum ventilation rate should be determined on the basis of national requirements, taking into account the building type and the pattern of occupancy for the building. The recommended value for dwellings is:

$$
n_{\min }=0,5 \mathrm{~h}^{-1} \text {. }
$$

On the other hand, hygienic requirements demand minimum of exhausted air from polluting spaces: kitchen $-72 \mathrm{~m}^{3} / \mathrm{h}$, bathroom $-54 \mathrm{~m}^{3} / \mathrm{h}$ and $\mathrm{WC}-36 \mathrm{~m}^{3} / \mathrm{h}$ [14]. Therefore total ventilation rate shall be determined as the greater of the minimum ventilation rate $L_{\min }$ and design ventilation rate $L_{v \cdot d}$.

Total $L_{v \cdot d}$ from polluting spaces equals $162 \mathrm{~m}^{3} / \mathrm{h}$. Mechanical ventilation is not permanently in use, therefore real air change rate in new housing is less. Value of additional uncontrolled air infiltration is recommended equal to $0,2 \mathrm{~h}^{-1}$, then resulting air change rate is assumed $0,7 \mathrm{~h}^{-1}$ and heat losses for heating of ventilation year are $67 \mathrm{kWh} / \mathrm{m}^{2}$.a $\left(20 \mathrm{kWh} / \mathrm{m}^{2}\right.$.a in the case of exhausted air heat utilisation).

\section{Heat consumption for hot water}

Values of heat consumption for domestic hot water supply are given bellow in Table 2 . Specific heat consumption depends very much on heated area per person, $\mathrm{m}^{2} /$ pers. behaviour of inhabitants hot water heat losses.

Mean real value of hot water consumption in Lithuania fluctuates in the limits of 30-50 liters/pers. day, mean actual useful area is $25 \mathrm{~m}^{2} /$ pers (flat area plus common use staircases, halls, etc.), then design values for the domestic hot water heat consumption are accepted $40 \mathrm{l} /$ pers. day and $25 \mathrm{~m}^{2} /$ pers.

Annual heat consumption is equal to:

$$
Q=g^{*} 51,17^{*} 365 / 1000 A, \mathrm{kWh} / \mathrm{m}^{2} . \mathrm{a},
$$

where $51,17 \mathrm{kWh} / \mathrm{m}^{3}$ of water is the officially accepted amount of energy for domestic water heating.

\section{Solar gains}

Part of solar radiation is excessive. If the building is better insulated or outdoor temperature is higher, then more solar radiation becomes excessive. Thus there is no common single numerical value of real solar gains for all cases. Mean value of solar radiation on the vertical surface during the heating season (months: Oct, Nov, Dec, Jan, Feb, Mar and Apr ) is $4,04 \mathrm{MJ} / \mathrm{m}^{2}$ day in Lithuania (Kaunas) or $46,7 \mathrm{~W} / \mathrm{m}^{2}$ [15]. Solar gains calculated with assumption that double glazed windows of 3-4 floors building (label A) are with light white curtains and windows area/floor area ratio equals 0,18 , gives result $5,1 \mathrm{~W} / \mathrm{m}^{2}$ floor $\left(26,9 \mathrm{kWh} / \mathrm{m}^{2} \mathrm{a}\right)$.

\section{Internal heat gains}

Internal heat gains recommended by LST EN 832 are equal to $5 \mathrm{~W} / \mathrm{m}^{2}$. STR 2.09 .04 [16] gives the values of internal gains in residential houses presented below: lighting $-3 \mathrm{~W} / \mathrm{m}^{2}$, domestic devices $-2,7 \mathrm{~W} / \mathrm{m}^{2}$, inhabitants $-2,8 \mathrm{~W} / \mathrm{m}^{2}$, or total $8,5 \mathrm{~W} / \mathrm{m}^{2}\left(45 \mathrm{kWh} / \mathrm{m}^{2} . \mathrm{a}\right)$.

Resulting value of internal heat gains is $8,5 \mathrm{~W} / \mathrm{m}^{2}$ or annually $45 \mathrm{kWh} / \mathrm{m}^{2}$.a. This figure seems to be too exaggerated - the transmission heat losses of a multiflat building are of the same range.

Taking into account the duration of various month artificial lighting, day absence of tenants and the area of common spaces more reliable value is $5 \mathrm{~W} / \mathrm{m}^{2}(24 \mathrm{kWh}$ $\mathrm{m}^{2}$.a.).

\section{Results}

The results of standard year annual heat consumption calculation are given in Tables 3, 4. Annual heat

\begin{tabular}{|c|c|c|c|c|}
\hline \multirow{2}{*}{$\begin{array}{l}\text { Hot water consumption } \\
\text { per person, } g, 1 / \text { day }\end{array}$} & \multirow{2}{*}{$\begin{array}{l}\text { Heated area, } \\
A, \mathrm{~m}^{2} / \text { person }\end{array}$} & \multirow{2}{*}{$\begin{array}{l}\text { Annual heat consumption, } \\
\text { kWh/pers.a }\end{array}$} & \multicolumn{2}{|c|}{ Specific heat consumption } \\
\hline & & & $q, \mathrm{kWh} / \mathrm{m}^{2} \mathrm{a}$ & $q, \mathrm{kWh} / \mathrm{m}^{3} \mathrm{a}$ \\
\hline \multirow{3}{*}{30} & 20 & \multirow{3}{*}{560} & 28,0 & 10,6 \\
\hline & 25 & & 22,4 & 8,5 \\
\hline & 30 & & 18,7 & 7,1 \\
\hline \multirow{3}{*}{40} & 20 & \multirow{3}{*}{749} & 37,3 & 14,2 \\
\hline & 25 & & 30,0 & 11,3 \\
\hline & 30 & & 24,9 & 9,4 \\
\hline \multirow{3}{*}{50} & 20 & \multirow{3}{*}{933} & 46,7 & 17,6 \\
\hline & 25 & & 37,3 & 14,1 \\
\hline & 30 & & 31,1 & 11,6 \\
\hline
\end{tabular}
losses for heating and ventilation are not defined for the

Table 2. Heat consumption for domestic hot water supply 
Table 3. Annual heat losses for heating and ventilation, $\mathrm{kWh} / \mathrm{m}^{2} \cdot \mathrm{a}$

\begin{tabular}{|c|c|c|c|c|c|c|c|c|c|}
\hline \multirow{2}{*}{ Label } & \multirow{2}{*}{$\begin{array}{c}\text { Corresponding } \\
\text { Regulation }\end{array}$} & \multicolumn{7}{|c|}{ Building description, number of floors } \\
\cline { 3 - 11 } & & 1 & $1-2$ & $\begin{array}{c}1-3 \\
\text { compl. shape }\end{array}$ & $\begin{array}{c}2 \\
\text { attached }\end{array}$ & $3-4$ & 5 & $6-9$ & $>10$ \\
\hline A & $\begin{array}{c}\text { Total heat demand } \\
\text { is limited }\end{array}$ & - & - & - & - & - & - & - & - \\
\hline B & STR2.05.01:1999 & 182 & 149 & 139 & 128 & 109 & 95 & 91 & 81 \\
\hline C & RSN143-92** & 212 & 185 & $178^{*}$ & $170^{*}$ & 157 & 143 & 130 & 120 \\
\hline D & - & 272 & 245 & 240 & 220 & 210 & 195 & 165 & 155 \\
\hline E & Soviet** & 384 & 350 & $333^{*}$ & $315^{*}$ & 282 & 251 & 229 & 197 \\
\hline
\end{tabular}

Note: * interpolated

** source: National Programme, 1996 [6].

Table 4. Total annual heat demand, $\mathrm{kWh} / \mathrm{m}^{2} \cdot \mathrm{a}$ (space heating, ventilation, domestic hot water, internal and solar heat gains included)

\begin{tabular}{|c|c|c|c|c|c|c|c|c|}
\hline Label & $\begin{array}{l}\text { Domestic hot water } \\
\text { excl/incl }\end{array}$ & 1 & $1-2$ & $\begin{array}{c}1-3, \\
\text { compl. shape }\end{array}$ & $\begin{array}{c}2 \\
\text { attached }\end{array}$ & $3-4$ & 5 & $\begin{array}{l}6 \text { and } \\
\text { more }\end{array}$ \\
\hline \multirow[t]{2}{*}{ A } & Excluding DHW & 113 & 84 & 71 & 54 & 40 & 32 & 31 \\
\hline & Including DHW & 139 & 110 & 97 & 80 & 66 & 58 & 57 \\
\hline \multirow[t]{2}{*}{ B } & Excluding DHW & 130 & 97 & 82 & 62 & 46 & 37 & 35 \\
\hline & Including DHW & 160 & 127 & 112 & 92 & 76 & 67 & 65 \\
\hline \multirow[t]{2}{*}{$\mathrm{C}$} & Excluding DHW & 162 & 133 & 126 & 118 & 105 & 91 & 78 \\
\hline & Including DHW & 192 & 163 & 156 & 148 & 135 & 121 & 108 \\
\hline \multirow[t]{2}{*}{ D } & Excluding DHW & 220 & 193 & 188 & 178 & 158 & 143 & 113 \\
\hline & Including DHW & 250 & 223 & 218 & 208 & 188 & 173 & 143 \\
\hline \multirow[t]{2}{*}{$\bar{E}$} & Excluding DHW & 348 & 314 & 297 & 279 & 246 & 215 & 193 \\
\hline & Including DHW & 378 & 344 & 327 & 309 & 276 & 245 & 223 \\
\hline
\end{tabular}

level A. These buildings are decided to have total heat consumption $15 \%$ less than level B. Recalculated values of level A total heat consumption are given in Table 4.

Table 4 contains values of annual heat consumption to maintain normal microlimatic conditions (heating, ventilation, domestic hot water minus internal and solar gains). Table 4 can serve as the first approximation defining annual heat demand labels.

The well-known figure of $70 \mathrm{kWh} / \mathrm{m}^{2}$.a of year heat consumption is valid for the mild climate of $\mathrm{W}$. European countries, it does not reflect the rigour of a climate Therefore the proposed annual heat consumption levels only in a few cases are below this value.

For energy conservation measures that are not included in the energy consumption calculation method but are already implemented in the building, in the label a certain amount of points are awarded. These points represent the energy amount that has been saved or the level of increased inside comfort. The points system can also be used to stimulate certain measures by giving them an extra reward. The most suitable point system for Lithuanian housing seems to be based on approximation in percentage to the higher level of energy efficiency. For example, implementation of individual measuring of heat consumption saves $29 \mathrm{kWh} / \mathrm{m}^{2} \mathrm{~K}$ in D level one floor building (difference between $\mathrm{C}$ and $\mathrm{D}$ levels is $58 \mathrm{kWh} /$ $\mathrm{m}^{2} \mathrm{~K}$ ). This would mean that the individual measuring would bring the label D up to the label DS0.
For new buildings, only one energy consumption calculation should be carried out and a table with recommendations for improvements rewarded with points should be given.

\section{Discussion}

The objective of EPC is to assess the total energy efficiency of a building and to provide information on possible energy efficiency improvements by heat consumption indicators.

Based on the current situation in Lithuania, EPC in Lithuania will mainly serve as an information and awareness tool. The certificate will serve as a reward to those homeowners (associations) that have taken energy efficiency measures. Experience with the Energy Efficiency Housing Pilot Project indicates that this has a positive influence on real estate values [17].

It is expected that the auditing and certification will be carried out by officially-approved (and possibly independent) experts and enterprises.

Costs should be kept as low as possible. The combination with the Building Passport is proposed, thus achieving an efficiency advantage [18].

Expected number of residential houses that could be reckoned to various levels of energy efficiency depends on heated area. Data charts of Kaunas housing stock allow rough estimation of the number of buildings 
corresponding to energy efficiency labels [19]: small houses (up to $500 \mathrm{~m}^{2}$ ) label $\mathrm{A}-20 \%, \mathrm{~B}-12 \%, \mathrm{C}-14 \%, \mathrm{D}-13 \%$,

E - $23 \%$, poor non-classified - $18 \%$; multiflat houses $\left(1000-6000 \mathrm{~m}^{2}\right)-$ label A - $3 \%, \mathrm{~B}-4 \%, \mathrm{C}-6 \%, \mathrm{D}-39 \%$, E $31 \%$, poor non-classified - $17 \%$.

Energy consumption in residential houses trends to diminish, peak of energy consumption curve has shifted from E label to D during the last 1997-2000 years. This tendency is welcomed although it took place not only thanks to energy saving measures but at the expense of tenants health when normal temperature is not being kept in buildings, the last case is especially characteristic of family houses.

\section{Conclusions}

1. In the European Union, EPC is regarded as a promising measure to increase energy efficiency in buildings. Within the framework of accession, Lithuania will have to comply with the requirements of the Save Directive and other EU legislation that require Member States to draw up programmes on energy performance certification. The method of energy performance efficiency calculation is proposed.

2. For Lithuania, the EPC indicators through labelling will mainly serve as an information and awareness tool. Given the current status of the building stock, stimulating building maintenance is regarded very important by the Lithuanian government, and therefore the EPC is linked to programmes on building maintenance.

3. There are proposed concrete values of annual heat consumption as energy efficiency indicators.

\section{References}

1. E C (2002): Amended Proposal for a Directive of the European Parliament and the Council on the energy performance of buildings, $\operatorname{COM(2002)~} 192$ final, 16 April 2002.

2. European Commission, 2001. Proposal for a Directive of the European Parliament and the Council on the Energy Performance of Buildings, COM (2001) 226 final.

3. Richalet, F. P.; Neirac, F.; Tellez, J.; Marco, J.; Bloem, J. HELP (house energy labeling procedure): methodology and present results, Energy and Buildings, Vol 33, 2001, p. $229-238$.

4. Zmereanu, R.; Fazio, P.; Delani, S.; Calla, R. Development of an energy rating system for existing houses. Energy and Buildings, Vol 29, 1999, p. 107Æ119.

5. Lithuanian Republic Ministry of Economy. National Programme of energy use efficiency increasing. Vilnius, 2001. 53 p. (short version).
6. Lithuanian Republic Ministry of Economy. Draft. National Programme of energy use efficiency increasing. Vilnius, 1996. 51 p. (short version).

7. Martinaitis, V. Energy saving possibilities and the demand of investments for multiflat buildings. In: Int. scientific conference „Decentralization of energetics“, 1999 Klaipeda, LEI, Kaunas, p. 85-90 (in Lithuanian).

8. Wees, M. T. van; Uyterlinde, M. A.; Kaan, H.; Arkel, W. G. van. The Dutch approach to energy performance certification of buildings. In: Energy supply for buildings, $5^{\text {th }}$ international conference „Environmental Engineering“, Proceedings 23-24 May 2002, Vilnius, p. 114-124.

9. Belindzeva-Korkla, $O$. Building energy consumption of the buildings as one of the major factors affecting building sustainability. In: Proceedings of int. workshop. Requirements to energy consumption level in buildings of the Baltic region, May 24-25, 2001, Kaunas, p. 50-59.

10. Pogorzelski, J. A. New Polish building code requirements on energy consumption for heating. In: Proceedings of int. workshop. Requirements to energy consumption level in buildings of the Baltic region, May 24-25, 2001, Kaunas, p. 84-90.

11. STR 2.05.01:1999. Regulation. Thermal Technique of Envelopes of the Buildings (Pastaty šilumos technika) (in Lithuanian).

12. RSN 143-92. Standard. Building Thermal Technique (Pastatu šilumos technika) (in Lithuanian).

13. LST EN $832+A C: 2000 \mathrm{en}$. Thermal performance of buildings. Calculation of energy use for heating. Residential buildings.

14. STR 2.09.02;1998. Regulation. Heating, ventilation and air conditioning (Šildymas, vedinimas ir oro kondicionavimas) (in Lithuanian).

15. RSN 156-94. Standard. Building climatology (Statybinè klimatologija) (in Lithuanian).

16. STR 2.09.04. Regulation. Peak power of building heating system. Energy use for heating (in Lithuanian).

17. Lašas, D.; Kazakevičius, E. Energy Efficiency Housing Pilot Project: Social and Technical Monitoring of Implemented Projects. In: Proceedings of the Building Renovation conference, Vilnius, 25 Nov. 1999.

18. Uyterlinde, M. A.; Kaan, H.; Jablonska, B.; Wees M.T. van, Cross E. D., Juškevičius P., Kazakevičius, E.; Juodis, E. Energy performance certification and labelling in the Lithuanian building sector. In: Energy supply for buildings, $5^{\text {th }}$ international conference „Environmental Engineering“", Proceedings 23-24 May 2002, Vilnius, p. 7379.

19. Karbauskaitè, J.; Stankevičius, V.; Paulauskaitè, S. Aspects of energy consumption in buildings. In: Energy supply for buildings, $5^{\text {th }}$ international conference "Environmental Engineering“, Proceedings 23-24 May 2002, Vilnius, p. $114-124$. 